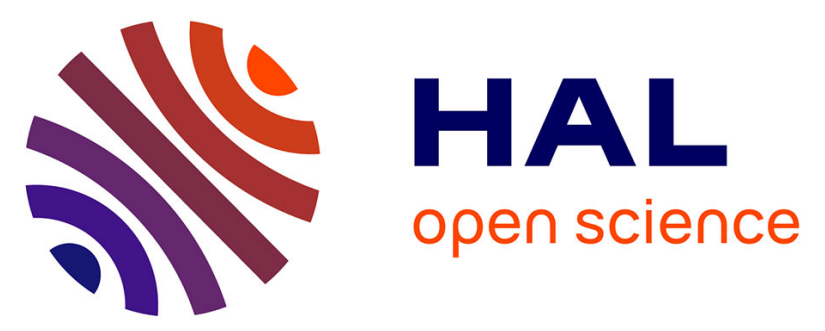

\title{
Transfer Hydrosilylation. Silyl Formates as Surrogates of Hydrosilanes and Their Application in the Transfer Hydrosilylation of Aldehydes
}

Clément Chauvier, Pierre Thuéry, Thibault Cantat

\section{To cite this version:}

Clément Chauvier, Pierre Thuéry, Thibault Cantat. Transfer Hydrosilylation. Silyl Formates as Surrogates of Hydrosilanes and Their Application in the Transfer Hydrosilylation of Aldehydes. Angewandte Chemie International Edition, 2016, 55, pp.14096 - 14100. 10.1002/anie.201607201 . cea-01391214

\author{
HAL Id: cea-01391214 \\ https://hal-cea.archives-ouvertes.fr/cea-01391214
}

Submitted on 21 Jan 2019

HAL is a multi-disciplinary open access archive for the deposit and dissemination of scientific research documents, whether they are published or not. The documents may come from teaching and research institutions in France or abroad, or from public or private research centers.
L'archive ouverte pluridisciplinaire HAL, est destinée au dépôt et à la diffusion de documents scientifiques de niveau recherche, publiés ou non, émanant des établissements d'enseignement et de recherche français ou étrangers, des laboratoires publics ou privés. 


\title{
Silyl Formates as Surrogates of Hydrosilanes and Their Application in the Transfer Hydrosilylation of Aldehydes
}

\author{
Clément Chauvier, Pierre Thuéry, and Thibault Cantat*
}

\begin{abstract}
Silyl formates are investigated for the first time as surrogates of hydrosilanes. In the presence of a well-defined ruthenium catalyst, these reagents are shown to promote the chemoselective reduction of a variety of aldehydes by transfer hydrosilylation. Mechanistic investigations have shown that genuine hydrosilane species are avoided during catalysis. The mechanism involves a sequence of decarboxylation/insertion/ transmetallation steps.
\end{abstract}

Catalytic hydrosilylation has found widespread applications in the silicon industry ${ }^{[1]}$ and in synthetic organic chemistry as it induces both reduction (hydro) and functionalization (silylation) of unsaturated bonds such as either $\mathrm{C}=\mathrm{C}^{[2]}$ or $\mathrm{C}=$ $\mathrm{O}^{[3]}$ in an atom-economical manner. Lately, the ability of hydrosilanes to cleave strong carbon-oxygen bonds, under mild conditions, has been exemplified in a variety of transformations aimed at reducing renewable feedstocks such as $\mathrm{CO}_{2}$ and biomass products. ${ }^{[4]}$ Nevertheless, the handling of pyrophoric, and possibly toxic and/or gaseous hydrosilanes (e.g., $\mathrm{SiH}_{4}$ ) raises safety issues.

To overcome these drawbacks, an option consists of the utilization of surrogates of hydrosilanes. In this respect, the group of Studer pioneered the use of silylated cyclohexa-1,4dienes (1,4-CHDN), obtained by Birch reduction of arenes with sodium and subsequent lithiation-silylation of the 1,4$\mathrm{CHDN}$, in the free-radical hydrosilylation of alkenes and aldehydes (Scheme 1) ${ }^{[5]}$ This concept of transfer hydrosilylation (THSi) was recently formalized by Oestreich et al. ${ }^{\left[{ }^{[6]}\right.}$ as a means to circumvent the use of gaseous $\mathrm{Me}_{3} \mathrm{SiH}$ or $\mathrm{SiH}_{4}$ in the ionic hydrosilylation of alkenes with $\mathrm{B}\left(\mathrm{C}_{6} \mathrm{~F}_{5}\right)_{3}{ }^{[7]}$ and the authors further extended this methodology to the reduction of alkynes, ketones and imines. ${ }^{[8]}$

In addition to the aforementioned safety concerns, the formation of hydrosilanes from chlorosilanes involves highly reactive and energy-demanding main-group-based hydrides such as $\mathrm{LiAlH}_{4} \cdot{ }^{\left[{ }^{[9]}\right.}$ In contrast, formic acid $\left(\mathrm{HCO}_{2} \mathrm{H}\right)$ possesses a redox potential close to that of hydrosilanes $\left(E^{\circ}\left(\mathrm{CO}_{2} /\right.\right.$ $\left.\mathrm{HCO}_{2} \mathrm{H}\right)=-0.11 \mathrm{~V} ; E^{\circ}\left(\mathrm{SiO}_{2} / \mathrm{SiH}_{4}\right)=-0.57 \mathrm{~V}$ vs. $\left.\mathrm{SHE}\right)^{[10]}$ and can be obtained by electroreduction of $\mathrm{CO}_{2}$ under mild reaction conditions. ${ }^{[11]}$ We thus reasoned that this reductant would be an attractive hydride source to access new hydro-

[*] C. Chauvier, Dr. P. Thuéry, Dr. T. Cantat NIMBE, CEA, CNRS, Université Paris-Saclay

Gif-sur-Yvette (France)

E-mail: thibault.cantat@cea.fr

Homepage: http://iramis.cea.fr/Pisp/thibault.cantat/index.htm

(2) Supporting information and the ORCID identification number(s) for

(iD the author(s) of this article can be found under http://dx.doi.org/10. 1002/anie.201607201.

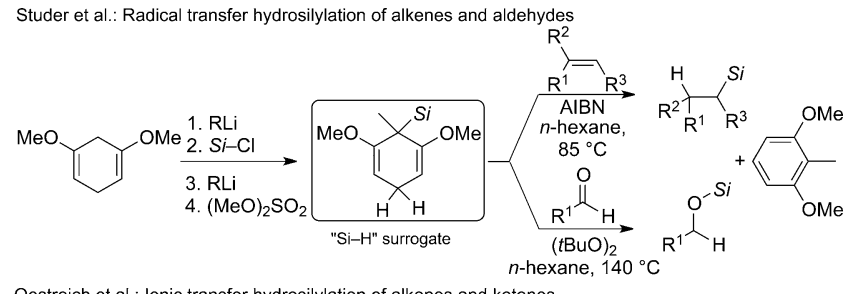

Oestreich et al.: Ionic transfer hydrosilylation of alkenes and ketones

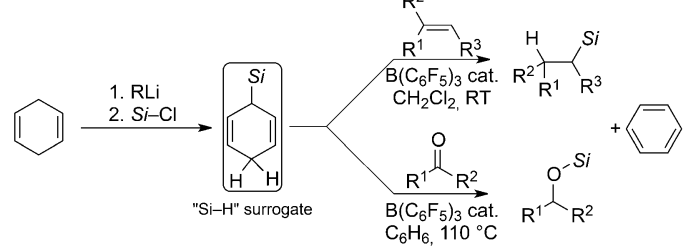

This work: Ru cat. transfer hydrosilylation of aldehydes

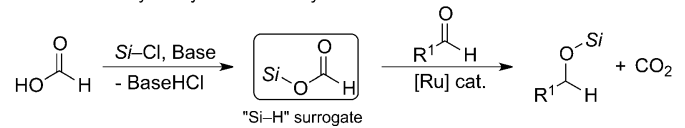

Scheme 1. Overview of published transfer hydrosilylation reactions of alkenes and carbonyls, and general strategy for the ruthenium-catalyzed THSi of aldehydes. AIBN=2,2'-azobis (2-methylpropionitrile).

silane surrogates, namely formoxysilanes $\left(\mathrm{R}_{3} \mathrm{SiOCHO}\right)$. Whereas $\mathrm{HCO}_{2} \mathrm{H}$ has been successfully utilized to generate hydrides in transition-metal ${ }^{[12]}$ and main-group elements ${ }^{[13]}$ chemistry, the reductive properties of formoxysilanes are largely underexplored. These compounds have indeed been mostly used as formylating agents ${ }^{[14]}$ and observed as intermediates in the hydrosilylation of $\mathrm{CO}_{2} \cdot{ }^{[15]}$ Herein, we show for the first time that formoxysilanes, readily prepared from formic acid and chlorosilanes, ${ }^{[16]}$ can serve as surrogates of hydrosilanes and their utility in transfer hydrosilylation is illustrated with the highly chemoselective reduction of aldehydes.

A variety of triorganosilyl formates (1-5) was selected to determine the influence of the silicon environment on the reactivity of the reductant (Figure 1) and the transfer hydrosilylation was firstly attempted using $\mathrm{Et}_{3} \mathrm{SiOCHO}$ (1) as a surrogate of the classical triethylsilane in the presence of benzaldehyde.

Anticipating that the cleavage of the formate $\mathrm{C}-\mathrm{H}$ bond in 1 would be kinetically challenging, we began our investigations by using the dimeric complex $\left[\left\{\mathrm{Ru}(p \text {-cymene }) \mathrm{Cl}_{2}\right\}_{2}\right]$ (6), which was shown to promote the catalytic dehydrogenation of formic acid. ${ }^{[17]}$ In the presence of $2 \mathrm{~mol} \%$ of $\mathbf{6}$, a $1: 1.2$ mixture of benzaldehyde (7a) and the silyl formate $\mathbf{1}$ provides the silyl ether $8 \mathbf{a}$ in $73 \%$ yield ( $73 \%$ conversion), after 26 hours at $100^{\circ} \mathrm{C}$ in $\mathrm{CH}_{3} \mathrm{CN}$ (Table 1, entry 1). 8a formally results from the hydrosilylation of $\mathbf{7 a}$ with $\mathrm{Et}_{3} \mathrm{SiH}$, thereby 


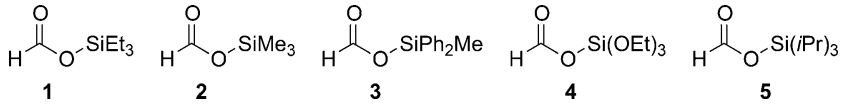

Figure 1. Silyl formates tested in this study as surrogates of hydrosilanes.

Table 1: Optimization of the THSi with 1 and $7 a^{[a]}$

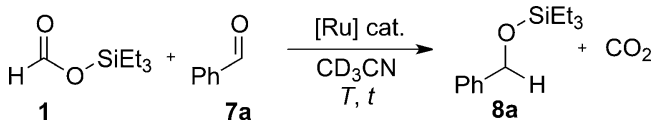

\begin{tabular}{|c|c|c|c|c|}
\hline Entry & [Ru] (mol\%) & Ligand & $t / T\left[{ }^{\circ} \mathrm{C}\right]$ & Yield of $8 \mathrm{a}[\%]^{[b]}$ \\
\hline 1 & {$\left[\left\{\mathrm{Ru}(p \text {-cymene }) \mathrm{Cl}_{2}\right\}_{2}\right](2)$} & - & $26 \mathrm{~h} / 100$ & 73 \\
\hline 2 & {$\left[\mathrm{RuCp} *(\mathrm{MeCN})_{3}\right] \mathrm{PF}_{6}(4)$} & - & $48 \mathrm{~h} / 100$ & $<5$ \\
\hline 3 & {$\left[\mathrm{Ru}(\mathrm{Me}-\mathrm{allyl})_{2}(\mathrm{COD})\right](4)$} & - & $7 \mathrm{~h} / 70$ & $>99$ \\
\hline 4 & {$\left[\mathrm{Ru}(\mathrm{Me}-\mathrm{allyl})_{2}(\mathrm{COD})\right](4)$} & dppp & $3.5 \mathrm{~h} / 70$ & $>99$ \\
\hline 5 & {$\left[\mathrm{Ru}(\mathrm{Me}-\mathrm{allyl})_{2}(\mathrm{COD})\right](4)$} & triphos & $50 \mathrm{~min} / 70$ & $>99$ \\
\hline 6 & 11 (4) & - & $5 \mathrm{~min} / 70$ & $>99$ \\
\hline 7 & $11(4)$ & - & $14 \mathrm{~h} / \mathrm{RT}$ & $>99$ \\
\hline 8 & $11(1)$ & - & $2.5 \mathrm{~h} / 70$ & 66 \\
\hline 9 & $11(2)$ & - & $0.5 \mathrm{~h} / 70$ & $>99(91)^{[c]}$ \\
\hline 10 & $11(2)$ & - & $4 \mathrm{~h} / 50$ & $>99$ \\
\hline
\end{tabular}

[a] Reaction conditions: $0.1 \mathrm{mmol} 7 \mathrm{a}, 0.12 \mathrm{mmol}$; solvent $(0.4 \mathrm{~mL}$; $0.25 \mathrm{M})$. [b] Yields determined by ${ }^{7} \mathrm{H}$ NMR analysis using mesitylene $(10 \mu \mathrm{L})$ as an internal standard. [c] Yield of product isolated from a $0.5 \mathrm{mmol}$ scale experiment. $\mathrm{Cp} *=\mathrm{C}_{5} \mathrm{Me}_{5}$.

proving that $\mathbf{1}$ is a competent surrogate of the hydrosilane. This finding was confirmed by the observation of $\mathrm{CO}_{2}$ release by ${ }^{13} \mathrm{C}$ NMR spectroscopy. Further improvement of the yield could not be achieved with longer reaction times, presumably because of the catalyst deactivation. The catalytic activity of different ruthenium complexes was thus explored. While no reaction was observed in the presence of the cationic complex $\left[\mathrm{RuCp} *(\mathrm{MeCN})_{3}\right] \mathrm{PF}_{6}(\mathbf{9}$; entry 2$)$ after 48 hours at $100^{\circ} \mathrm{C}$, full conversion of $7 \mathbf{a}$ into $8 \mathbf{a}$ was reached within 7 hours at $70^{\circ} \mathrm{C}$ with $\left[\mathrm{Ru}(\mathrm{Me} \text {-allyl })_{2}(\mathrm{COD})\right](\mathbf{1 0} ; \mathrm{COD}=1,5$-cyclooctadiene; entry 3 ). The addition of chelating phosphine ligands such as dppp (1,3-bis(diphenylphosphino)propane; entry 4), and the tripodal ligand triphos [1,1,1-tris(diphenylphosphinomethyl)ethane; entry 5] substantially improved the catalyst activity and stability, in line with the findings of Beller and co-workers in the dehydrogenation of formic acid with ruthenium(II) catalysts. ${ }^{[18]}$ Conversely, no reaction was noted in the absence of catalyst, even after $48 \mathrm{~h}$ at $100^{\circ} \mathrm{C}$.

Capitalizing on these observations, we assumed that a ruthenium(II) complex supported by the triphos ligand, and bearing two carboxylate ligands, would be a suitable precatalyst, able to yield a catalytically competent ruthenium formate complex upon transmetalation with $\mathbf{1}$. The stable $\left[\mathrm{Ru}\left(\kappa^{1}-\mathrm{OAc}\right)\left(\kappa^{2}-\mathrm{OAc}\right)\left(\kappa^{3}-\right.\right.$ triphos $\left.)\right]$ complex (11) was thus synthesized in $78 \%$ yield by reacting $\mathbf{1 0}$ with 2 equivalents of acetic acid and 1 equivalent of triphos in THF [Eq. (1); $\mathrm{THF}=$ tetrahydrofuran]. $\mathbf{1 1}$ was fully characterized by ${ }^{1} \mathrm{H}$, ${ }^{13} \mathrm{C}$, and ${ }^{31} \mathrm{P}$ NMR spectroscopy in combination with X-ray diffraction analysis (see the Supporting Information). ${ }^{[19]}$

Gratifyingly, $\mathbf{1 1}$ enables the formation of $\mathbf{8 a}$ in quantitative yield in 5 and 30 minutes at $70^{\circ} \mathrm{C}$, with a a catalyst loading of 4 and $2 \mathrm{~mol} \%$, respectively (Table 1, entries 6 and 9).
$\left[\mathrm{Ru}(\mathrm{Me}-\mathrm{ally})_{2}(\mathrm{COD})\right]+2 \mathrm{AcOH} \frac{\text { triphos }}{\mathrm{THF}_{15} 90^{\circ} \mathrm{C}} \underset{11}{\longrightarrow} \overbrace{\mathrm{O}} 78 \%$

Under these reaction conditions, $\mathbf{8 a}$ was isolated in $91 \%$ yield after column chromatography. Interestingly, $\mathbf{1 1}$ is also active at room temperature and the transfer hydrosilylation is complete after 14 hours at $25^{\circ} \mathrm{C}$ with 4 mol \% $\mathbf{1 1}$ (entry 7).

With the optimized reaction conditions in hand, the generality of the THSi was further evaluated with 2-5 (Scheme 2), as the nature of the silyl protecting group may be of importance in multistep syntheses. Pleasantly, $\mathrm{Me}_{3} \mathrm{SiOCHO}$ (2) readily reacted with benzaldehyde to

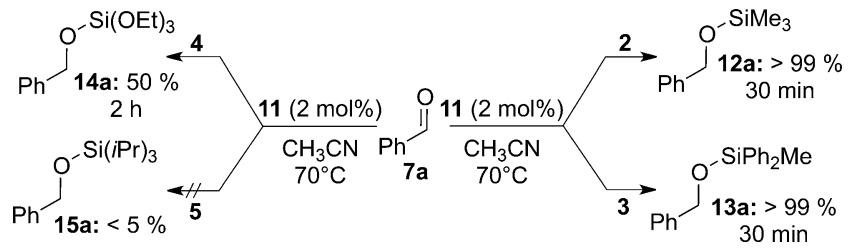

Scheme 2. Transfer hydrosilylation of 7a with 2-5.

afford the corresponding trimethylsilyl-protected alcohol 12a in quantitative yield after 30 minutes at $70^{\circ} \mathrm{C}$. 2 is thus a relevant surrogate of the gaseous and hazardous trimethylsilane and it provides an alternative to Oestreich's cyclohexa1,4-dienes for the THSi of aldehydes. ${ }^{[7 a]}$ While the reaction with the diphenylmethylsilyl derivative $\mathbf{3}$ worked equally well and afforded $\mathbf{1 3}$ a in a yield of greater than $99 \%$, the transfer of the TIPS group in $\mathbf{5}$ did not occur and only trace amounts of 14a were observed by ${ }^{1} \mathrm{H}$ NMR spectroscopy. Surprisingly, 4, a surrogate of the toxic triethoxysilane, which displays similar steric bulk to $\mathbf{1}$, reacted only sluggishly, thus leading to $\mathbf{1 4} \mathbf{a}$ in $50 \%$ yield after 2 hours. These data indicate that both steric and electronic effects influence the efficiency of the transfer hydrosilylation with silyl formates.

A collection of different functionalized aldehydes successfully underwent transfer hydrosilylation with $\mathbf{1}$ in excellent yields, within $30-90$ minutes at $70^{\circ} \mathrm{C}$, in the presence of 2 mol\% 11 (Table 2). The para-substituted benzaldehydes $\mathbf{7 b}-\mathbf{g}$, bearing halogens, ether, thioether, or alkyl groups were fully hydrosilylated into the silyl ethers $\mathbf{8 b} \mathbf{b}$ (entries 1-6). Increasing the steric bulk at the ortho position had no negative impact on the outcome of the reaction (entry 7). Importantly, oxidizing functionalities such as ketone, ester, cyano, or nitro groups were well-tolerated and the reactions proceeded chemoselectively to afford $\mathbf{8 i} \mathbf{i}-\mathbf{l}$ in excellent yields (>91\%; entries 8-11). While pyridine-2-carboxaldehyde (7n) is reduced within 30 minutes at $70^{\circ} \mathrm{C}$, the full conversion of para-dimethylamino benzaldehyde $(\mathbf{7} \mathbf{m})$ requires a somewhat longer reaction time of 90 minutes (entries 12 and 13). These results reveal that pyridine and amino coordinating groups do not poison the catalyst. Other heterocyclic aldehydes, rings, yielded the corresponding featuring furan, pyrrole, and thiophene protected primary alcohols quantitatively (entries 14-16). 
Table 2: Ruthenium-catalyzed THSi of aldehydes with 1. ${ }^{[a]}$

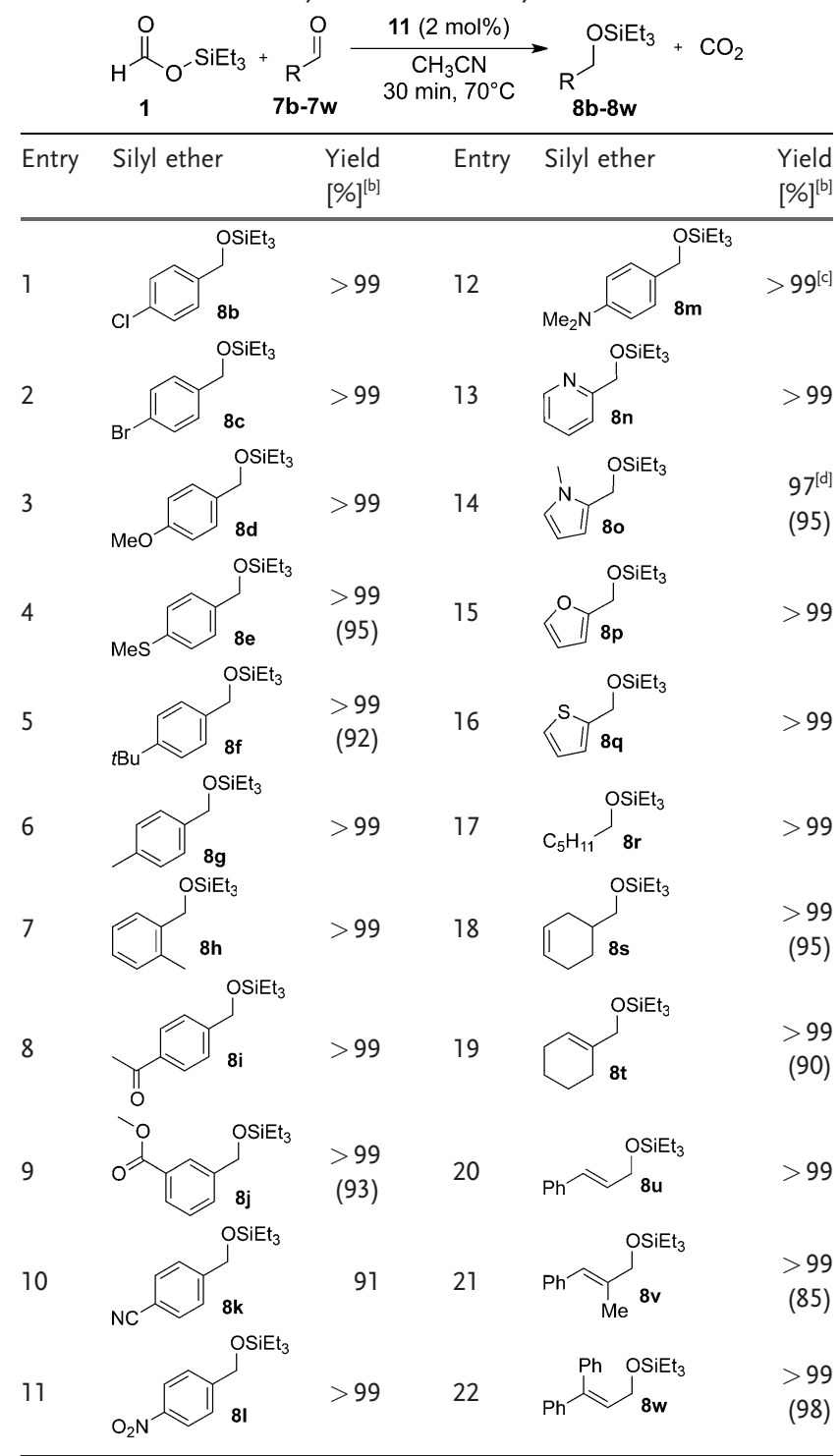

[a] Reaction conditions: aldehyde $(0.1 \mathrm{mmol}) ; 0.12 \mathrm{mmol} 1$; $\mathrm{MeCN}$ $(0.4 \mathrm{~mL} ; 0.2 \mathrm{M}) ; 30 \mathrm{~min}$ at $70^{\circ} \mathrm{C}$. [b] Yields determined by ${ }^{7} \mathrm{H}$ NMR analysis using mesitylene $(10 \mu \mathrm{L})$ as an internal standard. Yields of products isolated from scaled-up experiments $(0.5 \mathrm{mmol}$ scale) given within parentheses. [c] Full conversion reached within 1.5 h. [d] Full conversion reached within $1 \mathrm{~h}$.

Aliphatic and $\alpha, \beta$-unsaturated aldehydes are reluctant substrates in hydrogenation and transfer hydrogenation reactions because they can undergo side reactions, such as the formation of aldol products under basic conditions. ${ }^{[20]}$ Using our base-free protocol, the transfer hydrosilylation of hexanal and the cyclohexenal $\mathbf{7 s}$ resulted in the quantitative formation of $8 \mathbf{r}$ and $8 \mathbf{s}$, respectively, without observation of side products. Similarly, the double bond in the cyclohexene 7t (Table 2, entry 19) as well as in cinnamaldehyde derivatives 7u-w (entries 20-22) remained untouched.

In contrast, the reaction of acetophenone with $\mathbf{1}$ (or 2) under the same applied reaction conditions led to the complete recovery of the starting materials after 24 hours at $100^{\circ} \mathrm{C}$. The chemoselective transfer hydrosilylation of $\mathbf{7 i}$ into $\mathbf{8 i}$ with $\mathbf{1}$ and $\mathbf{1 1}$ as a catalyst (Table 2, entry 8) therefore does not result solely from a kinetically favored reduction of the aldehyde function but also from an absence of reactivity of the acetyl group.

The selective reduction of aldehydes over ketones is surprising given that the ruthenium-triphos system has been successfully used for the reduction of challenging substrates such as esters, carboxylic acids, and amides, under either hydrogenation or transfer hydrogenation conditions. ${ }^{[19,21]}$ The mechanism of the transfer hydrosilylation of benzaldehyde was thus studied both experimentally and by DFT calculations [M06/6-311+ G**/Ru(SDD)] with the model ligand $\mathrm{HC}\left(\mathrm{CH}_{2} \mathrm{PMe}_{2}\right)_{3}$ in place of triphos.

At the outset, the formation of $\mathrm{Et}_{3} \mathrm{SiH}$ by decarboxylation of $\mathbf{1}$ is slightly endergonic $\left(\Delta G=2.8 \mathrm{kcal} \mathrm{mol}^{-1}\right)$, thus suggesting that a bona fide hydrosilane is not formed during catalysis. Furthermore, reduction of $\mathbf{7 a}$ with $\mathrm{Et}_{3} \mathrm{SiH}$ only affords $\mathbf{8 a}$ in less than $10 \%$ yield after 24 hours at $70^{\circ} \mathrm{C}$, with $2 \mathrm{~mol} \% \mathbf{1 1}$ [Eq. (2)]. ${ }^{[22]}$ This result contrasts with the observation made by Oestreich et al. that the silylated 1,4-CHDN releases a hydrosilane reagent in the presence of the $\mathrm{B}\left(\mathrm{C}_{6} \mathrm{~F}_{5}\right)_{3}$ catalyst. $^{[7 a]}$

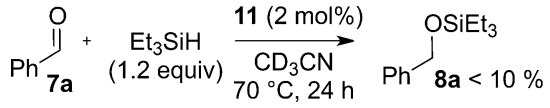

The addition of 4 equivalents of $\mathbf{1}$ to an acetonitrile solution of $\mathbf{1 1}$ resulted in the formation of a 48:52 mixture of the mono- and bis-formato complexes 16 and 17, within 5 minutes at room temperature (Scheme 3). The latter complexes undergo decarboxylation at room temperature to afford the known cationic complex $\left[\mathrm{RuH}\left(\kappa^{3}\right.\right.$-triphos $)$ $\left.(\mathrm{MeCN})_{2}\right]^{+} \quad\left(\mathbf{1 8} ; \quad \delta_{\mathrm{H}}=-5.6 \mathrm{ppm} ; \quad \mathrm{dt}, \quad{ }^{2} J_{\mathrm{P} c i s \mathrm{H}}=19.5 \mathrm{~Hz}\right.$, $\left.{ }^{2} J_{\mathrm{Ptrans \textrm {H }}}=104 \mathrm{~Hz}\right)$ as the sole hydride-containing species detected in solution. ${ }^{[23]}$ The complex $\mathbf{1 8}$ is also detected at the end of the catalytic runs. Subsequent addition of 1 equivalent of $\mathbf{7} \mathbf{a}$ to $\mathbf{1 8}$, in the presence of $\mathbf{1}$, resulted in the formation of $\mathbf{8} \mathbf{a}$ and the consumption of the hydride complex, within 5 minutes at room temperrature (see the Supporting Information for details).

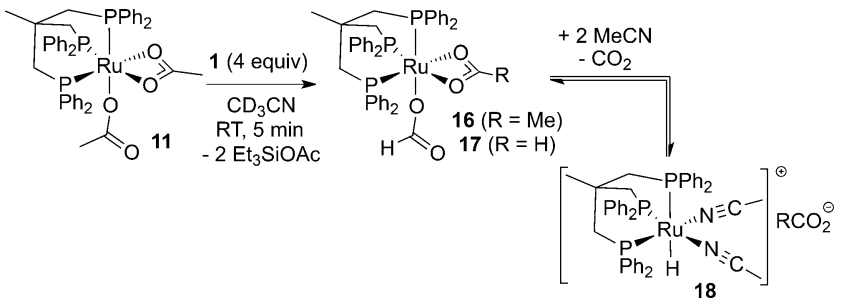

Scheme 3. Reaction of the complex 11 with 1 in acetonitrile.

The calculations further confirmed the ease of formation of hydrido complexes (see Schemes S2 and S3 in the Supporting Information). Notably, the decarboxylation of $\mathbf{1 7}^{[24]}$ to neutral $\left[\mathrm{RuH}\left(\kappa^{2}-\mathrm{OCHO}\right)\left(\kappa^{3}-\right.\right.$ triphos $\left.\left.^{\mathrm{Me}}\right)\right] \mathbf{1 9}$ requires a relatively low activation energy of $\Delta G^{+}=17.3 \mathrm{kcal} \mathrm{mol}^{-1}$ 


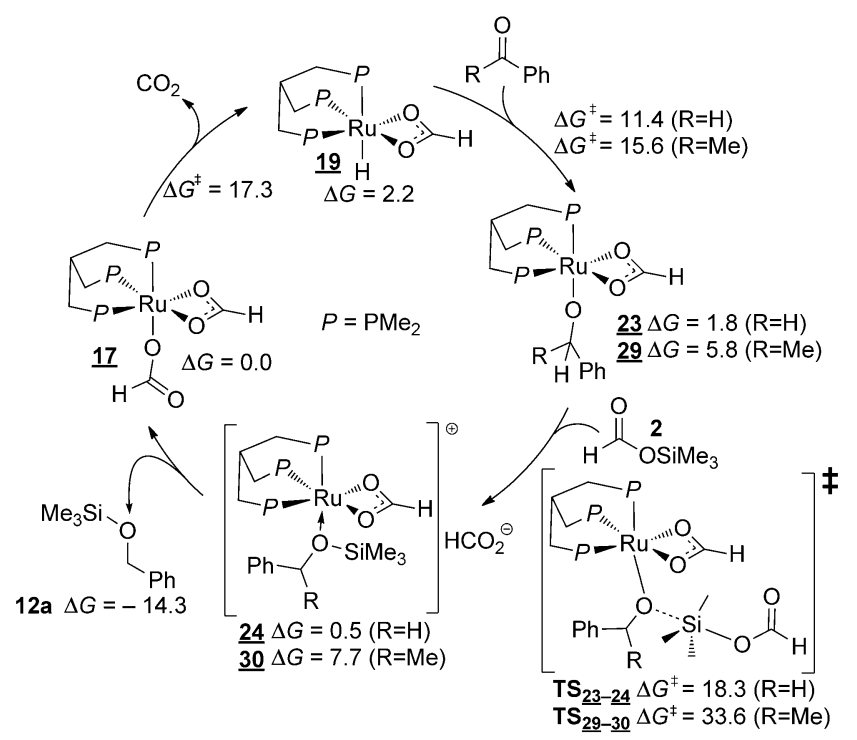

Scheme 4. Computed mechanism in acetonitrile (at the M06/6-311 $+\mathrm{G}^{\mathrm{N} *}(\mathrm{H}, \mathrm{C}, \mathrm{O}, \mathrm{P}, \mathrm{Si})+\mathrm{SDD}(\mathrm{Ru})$ level of theory) for the catalytic transfer hydrosilylation of benzaldehyde and acetophenone with $\mathbf{2}$ (free energies in $\mathrm{kcal} \mathrm{mol}^{-1}$ ).

(Scheme 4). The insertion of the $\mathrm{C}=\mathrm{O}$ bond of $7 \mathbf{a}$ into the $\mathrm{Ru}-\mathrm{H}$ bond of $\mathbf{1 9}$ is a rapid process and it affords the alkoxo complex 23. The latter interacts with $\mathbf{2}$ by an open transition state $\left(\Delta G^{+}=18.3 \mathrm{kcal} \mathrm{mol}^{-1}\right)$, which involves the external silylation of the alkoxide, followed by a barrierless release of the free $\mathrm{HCOO}^{-}$anion yielding the cationic 24. 17 is then formed by displacement of $\mathbf{1 2} \mathbf{a}$ with the formate anion in the secondary coordination sphere of ruthenium(II).

Interestingly, the potential energy surface is significantly modified when $\mathbf{7} \mathbf{a}$ is replaced with acetophenone (Schemes 4 and Scheme S4). While the energy barrier for insertion of the latter into the $\mathrm{Ru}-\mathrm{H}$ bond remains accessible $\left(\Delta G^{\neq}=\right.$ $15.6 \mathrm{kcal} \mathrm{mol}^{-1}$ vs. $\Delta G^{+}=11.4 \mathrm{kcal} \mathrm{mol}^{-1}$ for $\left.\mathbf{7 a}\right)$, the transmetallation step is strongly hampered by the presence of the secondary alkoxide and a high energy barrier of $33.6 \mathrm{kcal}$ $\mathrm{mol}^{-1}$ is computed to release the products. We therefore propose that the exceptional chemoselectivity of the transfer hydrosilylation primarily stems from the kinetic differentiation between primary and secondary alkoxides upon transmetalation.

In conclusion, we have shown for the first time that silyl formates are surrogates of hydrosilanes, thus enabling the chemoselective reduction of aldehydes with release of $\mathrm{CO}_{2}$, using well-defined ruthenium catalysts. Mechanistic investigations have shown that the mechanism involves a sequence of decarboxylation/insertion/transmetallation steps, thereby avoiding genuine hydrosilane intermediates.

\section{Experimental Section}

Detailed descriptions of experimental and computational methods are given in the Supporting Information.

\section{Acknowledgements}

For financial support of this work, we acknowledge CEA, CNRS, CINES (project c2016086494), the CHARMMMAT Laboratory of Excellence and the European Research Council (ERC Starting Grant Agreement n.336467). T.C. thanks the Foundation Louis D.- Institut de France for its support.

Keywords: hydrosilylation - density-functional calculations . reaction mechanisms · ruthenium · silanes

How to cite: Angew. Chem. Int. Ed. 2016, 55, 14096-14100 Angew. Chem. 2016, 128, 14302-14306

[1] a) Y. Nakajima, S. Shimada, $R S C A d v$. 2015, 5, 20603-20616; b) D. Troegel, J. Stohrer, Coord. Chem. Rev. 2011, 255, $1440-$ 1459.

[2] B. Marciniec in Hydrosilylation: A Comprehensive Review on Recent Advances (Ed.: B. Marciniec), Springer Netherlands, Dordrecht, 2009, pp. 3-51.

[3] a) S. Díez-González, S. P. Nolan, Org. Prep. Proced. Int. 2007, 39, $523-559$; b) B. Marciniec in Hydrosilylation: A Comprehensive Review on Recent Advances (Ed.: B. Marciniec), Springer Netherlands, Dordrecht, 2009, pp. 289-339.

[4] For a review on $\mathrm{CO}_{2}$ hydrosilylation, see: a) F. J. FernándezAlvarez, A. M. Aitani, L. A. Oro, Catal. Sci. Technol. 2014, 4, 611-624; For an example of lignin hydrosilylation, see: b) E. Feghali, G. Carrot, P. Thuery, C. Genre, T. Cantat, Energy Environ. Sci. 2015, 8, 2734-2743.

[5] a) S. Amrein, A. Timmermann, A. Studer, Org. Lett. 2001, 3 , 2357-2360; b) S. Amrein, A. Studer, Helv. Chim. Acta 2002, 85, $3559-3574$.

[6] M. Oestreich, Angew. Chem. Int. Ed. 2016, 55, 494-499; Angew. Chem. 2016, 128, 504-509.

[7] a) A. Simonneau, M. Oestreich, Angew. Chem. Int. Ed. 2013, 52, 11905-11907; Angew. Chem. 2013, 125, 12121-12124; b) A. Simonneau, M. Oestreich, Nat. Chem. 2015, 7, 816-822.

[8] S. Keess, A. Simonneau, M. Oestreich, Organometallics 2015, 34 , $790-799$.

[9] H. Gilman, R. K. Ingham, A. G. Smith, J. Org. Chem. 1953, 18, $1743-1749$.

[10] S. G. Bratsch, J. Phys. Chem. Ref. Data 1989, 18, 1-21.

[11] a) X. Lu, D. Y. C. Leung, H. Wang, M. K. H. Leung, J. Xuan, ChemElectroChem 2014, 1, 836-849; For production of formic acid by oxidation of biomass, see: b) R. Wölfel, N. Taccardi, A. Bosmann, P. Wasserscheid, Green Chem. 2011, 13, 2759-2763.

[12] a) A. Fujii, S. Hashiguchi, N. Uematsu, T. Ikariya, R. Noyori, J. Am. Chem. Soc. 1996, 118, 2521-2522; b) P. Hauwert, G. Maestri, J. W. Sprengers, M. Catellani, C. J. Elsevier, Angew. Chem. Int. Ed. 2008, 47, 3223-3226; Angew. Chem. 2008, 120, 3267-3270; c) G. Wienhöfer, I. Sorribes, A. Boddien, F. Westerhaus, K. Junge, H. Junge, R. Llusar, M. Beller, J. Am. Chem. Soc. 2011, 133, $12875-12879$.

[13] a) C. Chauvier, P. Thuery, T. Cantat, Chem. Sci. 2016, 7, 56805685 ; b) C. Chauvier, A. Tlili, C. Das Neves Gomes, P. Thuery, T. Cantat, Chem. Sci. 2015, 6, 2938-2942; c) M. Ohara, R. Okawara, J. Organomet. Chem. 1965, 3, 484-485.

[14] a) L. González-Sebastián, M. Flores-Alamo, J. J. García, Organometallics 2013, 32, 7186-7194; b) S. Itagaki, K. Yamaguchi, N. Mizuno, J. Mol. Catal. A 2013, 366, 347-352.

[15] a) A. Jansen, H. Görls, S. Pitter, Organometallics 2000, 19, 135138; b) W. Sattler, G. Parkin, J. Am. Chem. Soc. 2012, 134, $17462-17465$; c) L. Zhang, J. Cheng, Z. Hou, Chem. Commun. 2013, 49, 4782-4784; d) K. Motokura, D. Kashiwame, N. 
Takahashi, A. Miyaji, T. Baba, Chem. Eur. J. 2013, 19, $10030-$ 10037; e) R. Lalrempuia, M. Iglesias, V. Polo, P. J. Sanz Miguel, F. J. Fernández-Alvarez, J. J. Pérez-Torrente, L. A. Oro, Angew. Chem. Int. Ed. 2012, 51, 12824-12827; Angew. Chem. 2012, 124 , $12996-12999$; f) E. A. Jaseer, M. N. Akhtar, M. Osman, A. AlShammari, H. B. Oladipo, K. Garces, F. J. Fernandez-Alvarez, S. Al-Khattaf, L. A. Oro, Catal. Sci. Technol. 2015, 5, 274-279; For alternative preparations of silyl formates by dehydrogenative coupling, see: g) M. Chauhan, B. P. S. Chauhan, P. Boudjouk, Org. Lett. 2000, 2, 1027-1029; h) Y. Ojima, K. Yamaguchi, N. Mizuno, Adv. Synth. Catal. 2009, 351, 1405-1411.

[16] For preparations of silyl formates with chlorosilanes and salts of formic acid, see: a) A. G. Brook, J. Am. Chem. Soc. 1955, 77, 4827-4829; b) F. A. LeBlanc, W. E. Piers, M. Parvez, Angew. Chem. Int. Ed. 2014, 53, 789-792; Angew. Chem. 2014, 126, 808 811; c) C. C. Chong, R. Kinjo, Angew. Chem. Int. Ed. 2015, 54, 12116-12120; Angew. Chem. 2015, 127, 12284-12288.

[17] B. Loges, A. Boddien, H. Junge, M. Beller, Angew. Chem. Int. Ed. 2008, 47, 3962-3965; Angew. Chem. 2008, 120, 4026-4029.

[18] A. Boddien, B. Loges, H. Junge, M. Beller, ChemSusChem 2008, $1,751-758$.

[19] For another preparation of this complex, see: J. Coetzee, D. L. Dodds, J. Klankermayer, S. Brosinski, W. Leitner, A. M. Z. Slawin, D. J. Cole-Hamilton, Chem. Eur. J. 2013, 19, 1103911050.

[20] X. Wu, J. Liu, X. Li, A. Zanotti-Gerosa, F. Hancock, D. Vinci, J. Ruan, J. Xiao, Angew. Chem. Int. Ed. 2006, 45, 6718-6722; Angew. Chem. 2006, 118, 6870-6874.
[21] a) J. R. Cabrero-Antonino, E. Alberico, K. Junge, H. Junge, M. Beller, Chem. Sci. 2016, 7, 3432-3442; b) F. M. A. Geilen, B. Engendahl, M. Hölscher, J. Klankermayer, W. Leitner, J. Am. Chem. Soc. 2011, 133, 14349-14358; c) T. vom Stein, M. Meuresch, D. Limper, M. Schmitz, M. Hölscher, J. Coetzee, D. J. Cole-Hamilton, J. Klankermayer, W. Leitner, J. Am. Chem. Soc. 2014, 136, 13217-13225; d) S. Savourey, G. Lefèvre, J.-C. Berthet, P. Thuéry, C. Genre, T. Cantat, Angew. Chem. Int. Ed. 2014, 53, 10466-10470; Angew. Chem. 2014, 126, 10634-10638.

[22] For recent examples of ruthenium-catalyzed hydrosilylationo of aldehydes, see: a) B. Chatterjee, C. Gunanathan, Chem. Commun. 2014, 50, 888-890; b) Y. Do, J. Han, Y. H. Rhee, J. Park, Adv. Synth. Catal. 2011, 353, 3363-3366.

[23] a) C. Bianchini, A. Meli, S. Moneti, F. Vizza, Organometallics 1998, 17, 2636-2645; b) S. Wesselbaum, V. Moha, M. Meuresch, S. Brosinski, K. M. Thenert, J. Kothe, T. von Stein, U. Englert, M. Holscher, J. Klankermayer, W. Leitner, Chem. Sci. 2015, 6, $693-$ $704 ;$ c) DFT calculations suggest that $\mathbf{1 8}$ is a resting state of the catalyst (see the Supporting Information).

[24] Underlined numbers refer to complexes used in the calculations with the model ligand so as to distinguish them from their experimental counterparts.

Received: July 30, 2016

Revised: August 29, 2016

Published online: October 10, 2016 